Удк 377.017

DOI https://doi.org/10.32840/1992-5786.2021.74-2.32

\begin{abstract}
I. I. Драч
доктор педагогічних наук, доцент, перший заступник директора Інституту вищої освіти Національної академії педагогічних наук України
\end{abstract}

\title{
В. В. Поберецька
}

аспірант Інституту вищої освіти Національної академії педагогічних наук України, викладач фрілологічних дисциплін Барського гуманітарно-педагогічного коледжу імені Михайла Грушевського

\section{НАУКОВЕ ОБҐРУНТУВАННЯ МОДЕЛІ ПІДГОТОВКИ МАЙБУТНІХ ВЧИТЕЛІВ ПОЧАТКОВОЇ ОСВІТИ В ПЕДАГОГІЧНИХ КОЛЕДЖАХ ДО ІНТЕГРОВАНОГО НАВЧАННЯ УЧНІВ}

У статті представлено теоретичне обгрунтування моделі підготовки майбутніх вчителів початкової освіти в педагогічних коледжах до інтегрованого навчання учнів, що містить такі блоки: методологічно-цільовий, змістовно-процесуальний і результативний, які пов'язані між собою та впливають один на одного. Зазначено, що реалізація моделі сприятиме дослідженню основних характеристик підготовки вчителів початкової освіти; прогнозуванню результатів підготовки до інтегрованого навчання учнів та розв'язанню таких завдань: розвиток мотивації, педагогічного мислення студентів, їхніх здібностей; фрормування системи знань, педагогічних вмінь і навичок для здійснення інтегрованого навчання в практичній роботі з учнями, освоєння методів і прийомів педагогічної діяльності.

Визначено підходи (системний, аксіологічний, компетентнісний, інтеграційний) та принципи (гуманізація процесу навчання студентів педагогічним дисциплінам; фундаменталізація базових знань із педагогіки; принцип системності знань; фоормування позитивної мотивації до навчально-пізнавальної діяльності, активності і самостійності студентів) розробки моделі підготовки вчителів початкової освіти в педагогічних коледжах до інтегрованого навчання учнів; етапи її реалізації (підготовчий, практичний, коригуючий). Обгрунтовано доцільність використання традиційних та інноваційних фрорм і методів підготовки майбутніх вчителів початкової освіти в педагогічних коледжах до інтегрованого навчання учнів.

Представлено комплекс педагогічних умов, які сприяють успішній реалізації моделі: формування позитивної мотивації майбутніх вчителів початкової освіти до здійснення інтегрованого навчання учнів; оновлення змісту, фоорм і методів фрахової підготовки майбутніх вчителів шляхом включення компонентів, які відображають методологічні, теоретичні та методичні проблеми інтеграції в початковій освіті; застосування у процесі професійної підготовки інтегративних методів і форм навчання на аудиторних заняттях, під час практик, у самостійній роботі студентів для набуття досвіду використання та удосконалення навичок здійснення інтегрованого навчання учнів. Доведено, що спроектована модель дозволяє забезпечити єдність теорії і практики педагогічної діяльності.

Ключові слова: модель, педагогічний коледж, майбутні вчителі, підготовка, інтегроване навчання, початкова освіта.

Постановка проблеми. Згідно 3 новим Законом України «Про освіту» метою початкової освіти є всебічний розвиток, виховання і соціалізація особистості, яка здатна до життя в суспільстві та цивілізованої взаємодії з природою, має прагнення до самовдосконалення і навчання протягом життя, готова до свідомого життєвого вибору та самореалізації, відповідальності, трудової діяльності та громадянської активності [1].

Проблема підвищення якості освіти всебічно відображена в Концепції реалізації державної політики у сфері реформування загальної середньої освіти «Нова українська школа» на період до 2029 року, яка проголошує різнобічний розви- ток особистості дитини відповідно до її вікових та індивідуальних психофізіологічних особливостей, формування в неї загальнокультурних і морально-етичних цінностей, ключових і предметних компетентностей, необхідних життєвих і соціальних навичок, що забезпечують її готовність до продовження навчання в основній школі, життя у демократичному суспільстві [2].

Якість змісту початкової освіти передбачає засвоєння дітьми не тільки уявлень про навколишній світ і самого себе, але й найбільш істотних, природних, наочно представлених, доступних сприйняттю взаємозв'язків об'єктів і явищ навколишнього світу. Інтегрований зміст освіти 
насамперед забезпечує засвоєння таких взаємозв'язків і призводить до формування цілісних уявлень про світ. Аналіз досвіду практичної діяльності педагогічних коледжів у контексті досліджуваної проблеми дав змогу дійти висновку, що підготовка вчителів початкової освіти до інтегрованого навчання учнів ще не стала невід'ємним складником роботи усіх структурних підрозділів цих закладів. Тому однією із задач дослідження визначено теоретичне обґрунтування й розробку моделі підготовки вчителів початкової освіти до інтегрованого навчання учнів.

Аналіз останніх досліджень і публікацій. В Енциклопедії сучасної України під «моделлю» розуміють уявну чи матеріальну систему, яка «відображає або відтворює об'єкт дослідження і здатна змінювати його так, що ії̈ вивчення дає нову інформацію». Основною вимогою до моделі визначена її адекватність, тобто відповідність реальній дійсності, суттєвим властивостям об'єкта [3, с. 516]. На думку О. Дубасенюк, «методологія моделювання зорієнтована на аналіз, визначення умов та шляхів розвитку педагогічної освіти і потребує формування багаторівневої системи моделі» [4, с. 16].

У процесі розробки моделей Л. Капченко звертає увагу на визначення підструктур відносно цілісної системи і на пошук оптимальних зв'язків між ними [5]. Метод моделювання як інтегративний дозволяє досліджувати об'єкти у взаємозв'язку і проектувати логічні конструкції, що відображають педагогічне явище в розвитку. Дослідник О. Капінус пропонує використати моделювання для опосередкованого теоретичного дослідження педагогічного процесу на основі використання допоміжної штучної системи, яка перебуває в об'єктивному співвідношенні та відповідно до досліджуваного об'єкта здатна заміщати його на певних етапах пізнання [6, с. 85]. Ми погоджуємося з ним щодо того, що під час моделювання потрібно прагнути реалізувати певні функції, які властиві цьому процесові (ілюстративну, пояснювальну, критеріальну, прогностичну, перетворювальну).

Мета статті. Метою статті $€$ наукове обґрунтування моделі підготовки майбутніх вчителів початкової освіти в педагогічних коледжах до інтегрованого навчання учнів.

Виклад основного матеріалу. Моделювання означає матеріальне або уявне імітування реально існуючої системи шляхом створення спеціальних аналогів (моделей), у яких відтворюються принципи організації і функціонування цієї системи. Як показав аналіз науково-педагогічної літератури, моделювання охоплює практично всі ланки педагогічного процесу. Тому цілком обґрунтованою $є$ наша спроба розробити модель підготовки вчителів початкової освіти в педагогічних коледжах до інтегрованого навчання учнів. Отже, модель підготовки студентів - майбутніх вчителів до реалізації інтегрованого навчання передбачає досягнення кінцевого результату спеціально організованого освітнього процесу.

У моделі виокремлено такі основні блоки: методологічно-цільовий, змістовно-процесуальний і результативний, які пов'язані між собою та впливають один на одного. До складу методологічно-цільового блоку ми віднесли соціальне замовлення на підготовку компетентних вчителів початкової освіти, мету, завдання, методологічні підходи та принципи, суб'єктів освітнього процесу (студенти, викладацький склад, вчителі початкової освіти) та етапи реалізації моделі. Мета створення моделі дослідження основних характеристик підготовки вчителів початкової освіти; прогнозування результатів підготовки майбутніх педагогів та їхньої готовності до інтегрованого навчання учнів.

Модель призначена для розгляду підготовки вчителів початкової освіти у педагогічних коледжах як системи, яка має властивість трансорормації теоретичних знань у практичні вміння, дії. Отже, за допомогою моделі можна спроектувати умови забезпечення єдності теорії і практики педагогічної діяльності. Мета підготовки вчителів початкової освіти в педагогічних коледжах до інтегрованого навчання учнів спрямована на об'єднання розрізнених знань і вмінь із блоків навчальних дисциплін у цілісний особистісний комплекс, що забезпечує майбутнім вчителям готовність до майбутньої практичної діяльності (рис. 1). Вважаємо, що реалізація моделі сприятиме розвитку мотивації, педагогічного мислення студентів, їхніх здібностей; формуванню системи знань, педагогічних вмінь і навичок для здійснення інтегрованого навчання в практичній роботі з учнями, освоєння методів і прийомів педагогічної діяльності.

Таким чином, побудова та опис моделі дає уявлення про процес підготовки до інтегрованого навчання саме на основі інтеграції теорії і практики. Знання $з$ циклу дисциплін загальної та професійної підготовки стають рушійною силою студента для перетворення змодельованих дій у реальному освітньому процесі, оскільки вони співвідносяться 3 практикою. Теоретичною та методологічною основою для розробки моделі підготовки вчителів початкової освіти в педагогічних коледжах до інтегрованого навчання учнів $€$ використання як загальних дидактичних підходів до цього процесу, так і специфічних, зумовлених особливостями педагогічних інтеграційних процесів: системного, аксіологічного, компетентнісного, інтеграційного, тому що вони найбільше відповідають цілям і завданням дослідження.

Цільовий блок базується на таких принципах підготовки майбутніх вчителів: гуманізація процесу навчання студентів педагогічним дисциплінам; 
фундаменталізація базових знань із педагогіки; принцип системності знань; формування позитивної мотивації до навчально-пізнавальної діяльності, активності і самостійності студентів.

Моделюючи процес підготовки студентів педагогічних коледжів - майбутніх вчителів до інтегрованого навчання учнів, виділяємо такі етапи: підготовчий - аналіз вихідного стану (готовність студентів і освітнього середовища); практичний розроблення змісту та завдань підготовки майбутніх вчителів до реалізації інтегрованого навчання учнів; вибір педагогічних засобів; коригуючий діагностика готовності студентів до інтегрованого навчання.

Перший етап передбачає з'ясування і аналіз вихідного стану освітнього процесу в педагогічному коледжі з точки зору підготовки до інтегрованого навчання учнів, а також готовності студентів до реалізації інтеграційних процесів у школі, тобто діагностику їхніх знань про педагогічну інтеграцію, ставлення до проблем інтеграції, бажання оволодіти необхідними знаннями та вміннями.

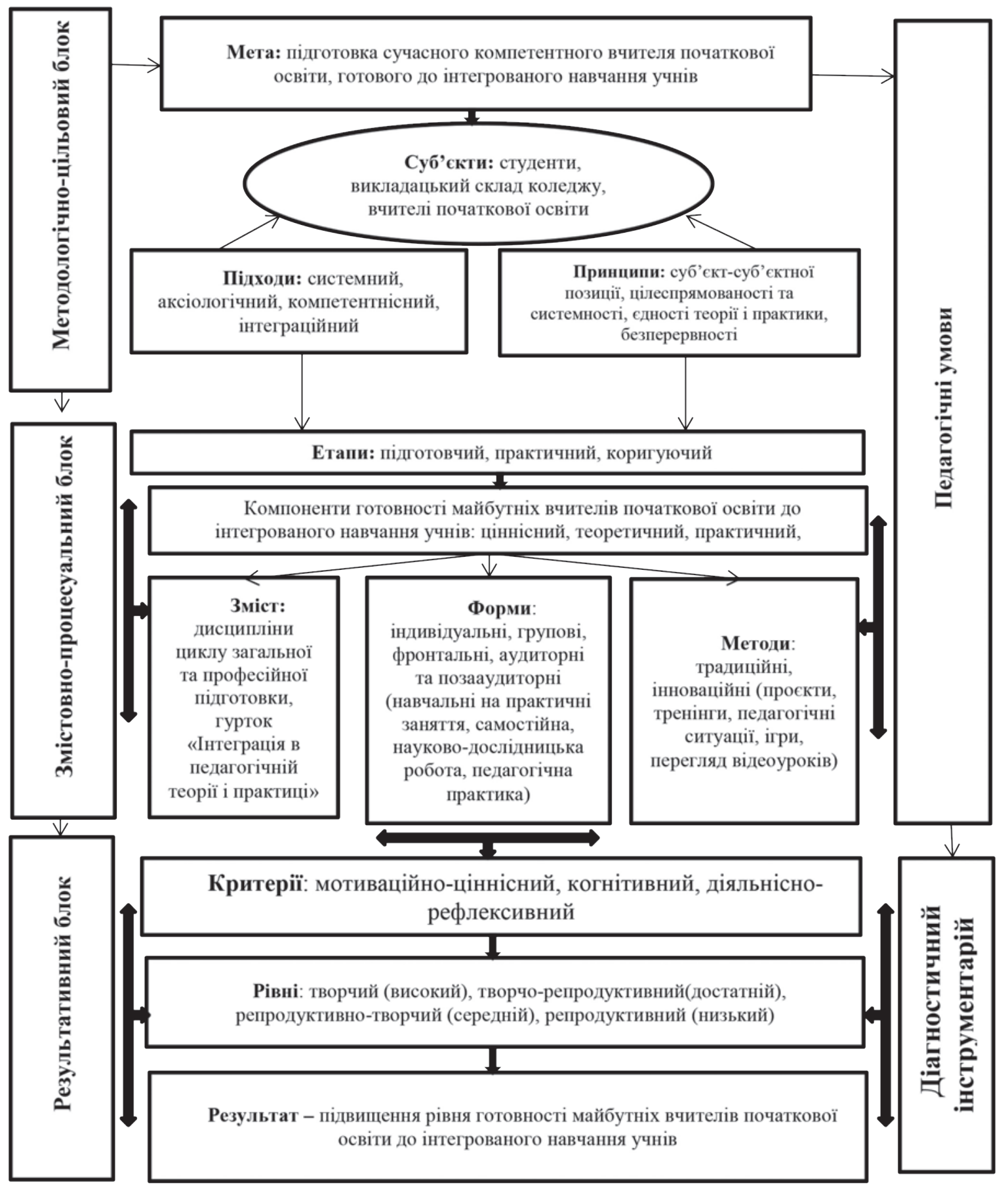

Рис. 1. Модель підготовки вчителів початкової освіти до інтегрованого навчання учнів 
Другий етап (практичний) передбачає реалізацію змістовно-процесуального блоку моделі підготовки студентів педагогічних коледжів - майбутніх вчителів початкової освіти до інтегрованого навчання учнів. Він включає зміст і завдання підготовки вчителів початкової освіти до інтегрованого навчання учнів, педагогічні умови, фрорми і методи ефрективного ії забезпечення в педагогічних коледжах.

Зміст і завдання підготовки майбутніх вчителів до реалізації інтегрованого навчання в початковій школі розроблялися відповідно до обґрунтованих компонентів готовності майбутніх вчителів початкової освіти до інтегрованого навчання учнів. Ціннісний компонент: виховання у студентів - майбутніх вчителів ставлення до навчання i майбутньої професійної діяльності як до творчого процесу; формування пізнавального інтересу до педагогічної проблеми, пов'язаної з інтеграційними процесами в шкільній освіті; формування усвідомленого розуміння актуальності інтеграції в освіті; фоормування потреби оволодіти теорією і практикою інтегрованого навчання.

Теоретичний компонент: набуття студентами знань про сутність, значення, форми, рівні, умови здійснення педагогічних інтеграційних процесів; ознайомлення з принципами побудови і характерними особливостями альтернативних інтегрованих курсів; принципами конструювання, критеріями й аналізом інтегрованого уроку; формування цілісного уявлення про взаємозалежність усіх компонентів процесу навчання в школі і ЗВО; вміння визначати і формулювати цілі інтегрованого навчання, проводити аналіз інтегрованого уроку.

Практичний компонент: розвиток вмінь і навичок розумової діяльності (аналізувати, зіставляти, порівнювати, проводити аналогію, робити висновки, доводити, спростовувати, встановлювати причинно-наслідкові залежності); професійних якостей (логічність, доказовість, критичність, гнучкість, рухливість, глибина); розвиток загальних і спеціальних професійних творчих здібностей на прикладі творчої реалізації інтеграційних процесів у початковій школі.

Рефлексивний компонент: формування почуття власної причетності до змін, пов'язаних із процесами інтеграції, які призводять до перетворень у школі; прагнення до розвитку готовності здійснювати інтеграційні процеси в початковій освіті; спрямованість на досягнення та вдосконалення у галузі інтегрованого навчання; ціннісні орієнтації на інтегроване навчання як на один із пріоритетних напрямів в освіті.

Змістовно-процесуальний блок моделі включає теоретичні основи дисциплін циклу загальної (гуманітарної та фрундаментальної) та професійної (психолого-педагогічної та науково-предмет- ної) підготовки. На практичному етапі реалізації моделі передбачено формування показників ціннісного та теоретичного компонентів готовності майбутніх вчителів початкової освіти до інтегрованого навчання учнів як основи для оволодіння практичним компонентом. Його мета полягає в забезпеченні змістовної методичної підготовки студентів до здійснення інтегрованого навчання учнів. Також цей етап підготовки студентів спрямований на засвоєння студентами тих навчальних дисциплін, які передбачені навчальною програмою закладу вищої освіти. Він передбачає поглиблення знань і фрормування на цій основі практичних навичок, покладених у фундамент вмінь здійснювати інтегроване навчання учнів у процесі професійної діяльності. На цьому етапі передбачене вже практичне застосування студентами елементів створення інтегрованих уроків. Він включає в себе педагогічну практику, під час якої студенти на практиці застосовують набуті знання.

Важливу роль у змістовно-процесуальному блоці моделі підготовки студентів педагогічних коледжів - майбутніх вчителів початкової освіти до інтегрованого навчання учнів мають навчальні дисципліни психолого-педагогічного та методичного циклів, під час вивчення яких відбувається формування окремих елементів знань і вмінь із педагогічної інтеграції.

Фрагментарне ж звернення до проблем педагогічної інтеграції не сприяє розвитку пізнавального інтересу та інтересу-потреби в здійсненні викладання на інтегративній основі. Лише при спеціально організованому і спрямованому навчанні можна викликати у майбутніх вчителів прагнення, потребу проникнути в цю пізнавальну область глибше, знайти бажання і можливість втілювати ідеї інтеграції в дійсності. Тому для посилення підготовки студентів до викладання на інтегративній основі розроблено змістові модулі окремих дисциплін, які сприятимуть набуттю знань щодо теоретичних і методичних основ інтеграції в початковій освіті та програми роботи студентського навчально-наукового гуртка «Інтеграція в педагогічній теорії і практиці».

У моделі підготовки вчителів початкової освіти в педагогічних коледжах до інтегрованого навчання учнів визначено та обґрунтовано комплекс педагогічних умов її реалізації: 1) формування позитивної мотивації майбутніх вчителів початкової освіти до здійснення інтегрованого навчання учнів; 2) оновлення змісту, форм і методів фрахової підготовки майбутніх вчителів через включення компонентів, які відображають методологічні, теоретичні та методичні проблеми інтеграції в початковій освіті; 3) застосування в процесі професійної підготовки інтегративних методів і форм навчання на аудиторних заняттях, під час практик, у самостійній роботі студентів для набуття досвіду 
використання та удосконалення навичок здійснення інтегрованого навчання учнів.

Підготовка студентів до інтегрованого навчання учнів початкової школи здійснюється протягом усього періоду неперервної підготовки студентів у педагогічних коледжах і реалізується у різних формах, які взаємопов'язані, доповнюють одна одну і створюють єдиний процес професійної підготовки майбутніх вчителів початкової освіти. Серед форм підготовки майбутніх вчителів початкової освіти до інтегрованого навчання учнів початкової школи визначаємо аудиторне навчання: лекції (проблемні, лекції-дискусії), лабораторні, практичні та семінарські заняття (робота в малих групах, тренінги з вирішення педагогічних задач) та позааудиторне навчання (самостійна та індивідуальна робота, науково-дослідницька робота, педагогічна практика). Самостійна та індивідуальна робота студентів у процесі створення інтегрованих уроків спонукає до самостійності студентів, сприяє кращому засвоєнню навчального матеріалу. Ці фрорми взаємопов'язані, взаємодоповнювані та забезпечують єдиний процес підготовки майбутніх фахівців до інтегрованого навчання учнів.

У контексті нашого дослідження педагогічну практику розглядаємо як важливий засіб підготовки вчителів початкової освіти в педагогічних коледжах до інтегрованого навчання учнів. Вона дозволяє поглибити знання, набуті під час навчання та самостійної роботи майбутніх педагогів, сприяє якісним змінам усіх компонентів їхньої професійної готовності, дає змогу отримати практичний досвід, виявити основні недоліки, своєчасно внести необхідні корективи в подальшу підготовку [7].

До основних методів підготовки майбутніх вчителів початкової освіти в педагогічних коледжах до інтегрованого навчання учнів відносимо традиційні та інноваційні методи. Традиційні: словесні, активні, дидактичні ігри, перегляд відеоуроків, спостереження та аналіз, метод проєктів, метод мозкового штурму, репродуктивні, проблемно-пошукові, методи контролю і самоконтролю. Інноваційні: case-stady, e-learning, перевернуте навчання, проблемні ситуації. Специфріка змісту та процесу підготовки майбутніх вчителів початкової освіти в педагогічних коледжах до інтегрованого навчання учнів потребує використання різних засобів навчання - допоміжних матеріальних засобів 3 їхніми специфічними дидактичними функціями.

Ми погоджуємося із твердженням Д. Возносименко, що використання всіх наведених форм, засобів і методів навчання у підготовці майбутніх вчителів, а також впровадження моделі можливе лише шляхом концентрації зусиль та узгодженої взаємодії усіх суб'єктів освітнього процесу [8].
Особливо варто звернути увагу на спеціальні засоби навчання - відеозаписи уроків вчителів початкових класів і студентів-практикантів, які використовуються на заняттях у педагогічному коледжі під час вивчення різних навчальних курсів; відеозаписи інтегрованих уроків у початкових класах; конспекти інтегрованих уроків.

Результативний блок моделі охоплює критерії, рівні готовності вчителів початкової освіти до інтегрованого навчання учнів як певний результат, що реалізується на коригуючому етапі моделі. Цей етап передбачає рефлексію власної діяльності та фрормування рефлексивного компоненту готовності майбутніх вчителів початкової освіти до інтегрованого навчання учнів. Оцінювання результативності моделі здійснювалося шляхом аналізу динаміки рівнів сформованості компонентів готовності за визначеними критеріями за допомогою комплексу діагностичних методик.

Висновки і пропозиції. Таким чином, моделювання підготовки вчителів початкової освіти в педагогічних коледжах до інтегрованого навчання учнів дає підстави для таких тверджень: освітній процес професійної підготовки майбутніх вчителів початкової освіти у педагогічних коледжах включає в себе інтеграцію навчальних дисциплін; основними ознаками моделі як системи є цілісність, що виявляється в єдності теорії і практики, процес професійної освіти орієнтований на освоєння стандарту вищої педагогічної освіти кожним студентом, на взаємопов'язаність елементів в єдине ціле; керованість цього процесу гарантується орієнтацією на модель, що забезпечує цілепокладання, планування, проектування такого виду підготовки, зворотним зв'язком на основі оперативної оцінки вмінь студентів; розроблена модель забезпечує більш високий рівень освоєння студентами методів і прийомів інтегрованого навчання учнів; спроектована модель має властивість відтворюваності в системі професійної підготовки вчителів у педагогічних коледжах.

Передбачувана ефективність підготовки вчителів початкової освіти в педагогічних коледжах на основі розробленої моделі представлена такими позиціями: вирішується проблема мотивації вивчення педагогіки, оскільки теоретичне знання $€$ основою для освоєння наскрізних педагогічних вмінь; розвиваються творчі здібності учасників освітнього процесу (викладачів і студентів); навчальний матеріал визначається відповідно до логіки мети і змісту освіти; забезпечується підвищення готовності до інтегрованого навчання учнів на основі інтеграції теорії і практики. Така модель відображає загальні умови, які забезпечують підготовку студентів - майбутніх вчителів початкової освіти до інтегрованого навчання учнів і потребує експериментальної перевірки. 


\section{Список використаної літератури:}

1. Закон України «Про освіту». 2017. Вебсайт. URL: https://zakon.rada.gov.ua/laws/ show/2145-19\#Text вата звнення: 20.01.2021).

2. Концепція нової української школи. Веб-сайт. URL: $\quad$ https://mon.gov.ua/storage/app/media/ zagalna\%20serednya/nova-ukrainska-shkolacompressed.pdf (дата звернення: 22.01.2021).

3. Енциклопедія сучасної України (Encyclopedia of modern Ukraine). Веб-сайт. URL: http://esu. com.ua/search_articles.php?id=12384 (дата звернення: 22.01.2021).

4. Професійна педагогічна освіта: інноваційні технології та методики : монографія / за ред. О.А. Дубасенюк. Житомир : Вид-во ЖДУ ім. І. Франка, 2009. 504 с.

5. Капченко Л.М. Моделювання організаційно-педагогічної діяльності в системі управління про- фесійно-технічними навчальними закладами : автореф. дис. канд. пед. наук: 13.00.07. Київ, 2002. 20 c.

6. Капінус О.С. Практичні підходи до побудови моделі фрормування соціальної відповідальності у майбутніх офріцерів на основі застосування засобів інтерактивних технологій. Науковий вісник Чернівецького університету : зб. наук. пр. Чернівці, 2014. Вип. 679: Педагогіка та психологія. С. 83-91.

7. Галузяк В.М., Сметанський М.І., Шахов В.І. Педагогіка : навч. посіб. Вінниця : Державна картографічна фрабрика, 2006. 400 с.

8. Возносименко Д.А. Методичне забезпечення підготовки майбутніх вчителів математики до здійснення валеологічного супроводу навчання учнів математики. Проблеми підготовки сучасного вчителя : зб. наук. пр. Умань, 2019. Вип. 19. С. 31-38.

Drach I., Poberetska V. Scientific substantiation of the model of training future teachers of primary education in pedagogical colleges for integrated student learning

The article presents a theoretical justification of the model of preparation of future primary school teachers in pedagogical colleges for integrated student learning. Theoretical analysis of the modeling method as a theoretical study of the pedagogical process is carried out. The blocks of the model are distinguished: methodological-target, content-procedural and effective, which are interconnected and influence each other. It is noted that the implementation of the model will help solve the following tasks: the development of motivation, pedagogical thinking of students, their abilities; formation of a system of knowledge, pedagogical skills and abilities for the implementation of integrated learning in practical work with students, development of methods and techniques of pedagogical activity.

Approaches (systemic, axiological, competence, integration) and principles (humanization of the process of teaching students pedagogical disciplines; fundamentalization of basic knowledge in pedagogy; systematic knowledge; formation of positive motivation for educational and cognitive activity, activity and independence of students) of development of model of preparation of teachers of primary education in pedagogical colleges for integrated training of pupils; stages of its implementation are defined. The expediency of using traditional and innovative forms and methods of preparation of future primary education teachers in pedagogical colleges for integrated teaching of students is substantiated.

A set of pedagogical conditions, that contribute to the successful implementation of the model is presented: the formation of positive motivation of future primary school teachers to implement integrated student learning; updating the content, forms and methods of professional training of future teachers through the inclusion of components that reflect the methodological, theoretical and methodological problems of integration in primary education; application in the process of professional training of integrative methods and forms of teaching in the classroom, during internships, in independent work of students to gain experience in using and improving the skills of integrated learning of students.

Key words: model, pedagogical college, future teachers, preparation, integrated learning, primary education. 